\title{
Strengthening Federalism Through Charter Decisions
}

\author{
BRENT RANDALL
}

The Constitution Act, 1982, containing the Charter of Rights and Freedoms, is seen by many to be a major victory for individual liberty. The Charter is seen as a ground-breaking provision, but it is also at the mercy of interpretation. Like the Constitution containing it, there are many ambiguous terms which inevitably demand application when settling disputes between two parties. This requirement of interpretation can turn the Charter from celebrated to controversial depending on the interests involved. In Canada, provincial and federal legislatures are most often in charge of interpreting the Constitution favourably by creating laws that capture the spirit of the document. If for some reason there is concern with how the Constitution, and Charter, is interpreted through this legislation, the Supreme Court of Canada is the final decision-maker on its validity. This judicial review is the source of much debate, for a couple reasons. First, some take exception to the Supreme Court having the final say on rights issues. Second, when it is applied in such a way, the Charter seems to centralize power and create a 
pan-Canadian rights regime

orchestrated by the Court. These two

points of interest are what I will be

focusing on.

In this paper I will start by

briefly looking at the current nature of

Canada's Charter of Rights and

Freedoms. I will then look at the

relationship between the Supreme

Court and the federal and provincial

legislatures in the case of dealing with

Charter disputes and what it implies

for the current state of rights in

Canada. This will be followed by a look at section 33 of the Charter, the

Notwithstanding Clause. I will talk

about its importance, and what the

stigma of enacting it means for the

balance of power on Charter conflicts.

I will then offer how I think this

balance of power can be restored and

maintained. Along the way I hope to

defend my statements from counter-

arguments that may arise. My aim is

to show that the current method of

applying the Charter is incompatible

with the goal of maintaining a strong

Canadian federation.

The Charter of Rights and

Freedoms is a provision in the
Canadian Constitution very similar to the Bill of Rights enacted in 1960.

The main difference is that unlike the Bill of Rights, the Charter has been entrenched in the Constitution, giving it much more legitimacy when settling disputes. Janet Hiebert notes that the Bill of Rights was intended to make Parliament the ultimate decisionmaker on rights disputes. Critics argue that when the Charter was created it shifted this reliance away from Parliament, but Hiebert disagrees, stating that she believes Parliament still has a key role in interpreting the Charter (Hiebert 2002: 4). Hiebert's sentiment aligns perfectly with standard political belief - that Parliament, or even more specifically, federal and provincial governments, should be one of the major players in deciding how to best apply the Charter. The problem arises in the fact that these legislatures must share the power of interpretation with the Supreme Court of Canada if rights disputes are pushed far enough. This sharing of power is not easily managed. Hiebert states that a reason this has become more of a 
power struggle is because of the changing attitude of the Supreme Court. The Court used to believe that if they were to rule on differences of values of society, it would be misplaced and that such decisions should be made by legislatures. Now, however, they collectively see themselves as "guardian of the Constitution" (Hiebert 2002: 21).

It is important to note that the Supreme Court is not simply powerhungry, snatching away the balance of power away from the legislatures. Rather, it seems that the nature of our system has fed into this shift. As F.L. Morton argues, it is often a better move politically for governments to defer difficult rights questions to the Court. In remaining as neutral as possible, they avoid developing rifts within their party, as well as their constituencies (Morton 1999: 26). Since the Court has been given the final decision anyway, legislatures are able to save face while still getting some kind of results for their region. Legislatures seem to have accepted that instead of a dialogue with the Court, there is instead a monologue or a chain of command with the judiciary at the top giving orders (Morton 1999).

The Canadian system was certainly not intended to have this top-down approach. Sir John A. MacDonald thought that the division of power in this country would be clearly laid out so that judicial review of federal-provincial disputes would be unnecessary (Manfredi 2001: 12). The Notwithstanding Clause, which will be discussed later, was also supposed to even the playing field so that the legislatures would have a shield against the decisions of the Supreme Court. With plenty of power struggles between federal and provincial governments, and a nearly nonexistent Notwithstanding Clause, it is clear that the current Canadian legal landscape did not work out how MacDonald or the framers of the Constitution had anticipated. There are a few reasons why the relationship between the Court and legislatures evolved this way.

As Jennifer Smith points out, the provinces were mostly cold to the idea of the Charter because it was seen as a limit on their autonomy. 
The main source of this negativity stems from the fact that Supreme Court Justices are appointed by the federal government. Opponents to this view argue that judicial decisions apply to the federal level as much as the provincial, and that the judiciary is its own independent body, and therefore free from potentially biasing influences (Smith 2004: 61). While it is easy to understand the counterpoint to the provincial concerns, it is hard to buy into its real world implications. This is not to say that it is certain the Supreme Court would be biased toward the federal government, since that is how they are appointed. However, it is only natural, in our democratic country, to be sceptical about any appointed officials even if they are appointed to the highest Court in the land. It would be nice to think that the Supreme Court is an independent body, free from any sort of political influence, and it certainly is possible. The trouble is that there are also going to be questions raised about the legitimacy of an appointed body, and those questions are being raised here by the provincial legislatures.

Not only is there concern of bias toward the federal government, but the Charter is also seen by some as a way of centralizing public policy. By concentrating so much power into the Supreme Court, it appears as though the Charter becomes pan-Canadian. Since one centralized body is responsible for dealing with Charter disputes across the country, there is bound to be a certain amount of conformity to specific values that the Court applies in their cases. This is not really a fault of the Court. With the same people presiding over all cases it is only natural for their personal moral standards to be an influence in their decisions. This is also precisely the reason why the power dynamic for Charter conflicts needs to be adjusted. Allowing the Supreme Court the ability to deliberate and issue a verdict is useful, but they may not be as aware of specific intricacies and differences between cultures and regions of Canada that are important to getting the case right. If these details are 
missed, then there is the danger of not having the Charter work equally for everyone, and thus unbalanced treatment for all parts of the federation. This is where the legislatures need to be able to step in as a similarly powerful entity and engage in a dialogue with the Court to make the best judgment.

F.L. Morton, in his biting critique of the current system of deciding rights disputes, encapsulates the way decisions are actually made in Canada by looking at the fallout of the 1988 Morgentaler ruling. He writes about how Justice Lamer, who struck down the abortion provisions in the Criminal Code based on procedural concerns, later went on record in 1998 saying he struck it down because (he thought) a majority of Canadians were against making it a criminal offence. The Mulroney government was then forced to enact a new abortion policy in light of the Morgentaler ruling thinking that the Court's real problem was in the procedure for getting an abortion (Morton 1999: 24-25).

Morton's account presents two important points of interest. One, it shows the nature of the relationship between the Court and the government on creating rights legislation. This is the new decisionmaking process that has emerged - a piece of legislation is questioned, brought to the Court, the Court decides, and the legislature must cater to their demands if necessary. It is not hard to see why Morton claims there is little dialogue between the two. This lack of dialogue can prove damaging for the dynamics of federalism. Canadian federalism, whether it is actually realized in the day-to-day workings of the country, is intended to be a system based on shared rule between equal interests in the federation. If one interest, in this case the Supreme Court, is far from equal then the system is compromised. The aim of federalism in Canada is to balance interests and powers, but the Supreme Court dictating to legislatures, as often is the case, does not fulfill this aim.

The Morgentaler fallout also shows us that the Supreme Court is not infallible or perfectly moral actors as we sometimes might naively 
assume based on their high ranking. As previously outlined by Morton, Lamer officially opposed abortion provisions in the Criminal Code because he thought some of the language surrounding its legality was too ambiguous. He later stated he really opposed the provision because he believed most Canadians were opposed to making it a criminal offence, even though that was incorrect. It is hard to avoid thinking that Lamer's decision was made dubiously. In his official decision, Lamer was opposed to the provision based on descriptive grounds - he believed that there needed to be clarification. In actuality, Lamer's opposition came from his (misplaced) normative beliefs - that abortion should not be a criminal offence because most Canadians felt that way. This naturally leads to a question of how we want the Supreme Court to operate. Do we want strict application of the Charter to the letter, or do we want to make sure that human moral judgment and reason, which can be fallible, come into play as well? It would seem that we want a balance of both, but finding this equilibrium can be tough or nearly impossible and feeds into the troubled relationship. An additional tension that has been only mentioned, and runs alongside the others is the fact that the judiciary decisions contain finality. This power has major implications for how we view the Court as well as constitutional law in general. Christopher P. Manfredi goes so far as to say that it creates a paradox for liberal constitutionalism. By enforcing the constitution as being the most powerful, Manfredi argues that it is the judiciary which is actually the most powerful by way of its responsibility for such enforcement (Manfredi 2001: 22). This implies that it is the Supreme Court who must ultimately be pleased, rather than the provisions of the Charter.

Furthermore, this ultimate power perpetuates the belief that the Supreme Court justices are the ultimate moral actors. Both of these consequences are unfavourable in a federal system under a constitution. James Kelly challenges this idea, what he calls the "myth of 
judicial supremacy." He argues that judicial activism does not necessarily lead to judicial supremacy (Kelly 2002: 98). This is a valid argument from Kelly. Judicial activism does indeed not necessarily lead to judicial supremacy, but it is hard to deny that the Canadian system gives the judiciary considerable power over legislatures as previously outlined. There is no problem with the judiciary being able to review legislation, but rather the way the system allows the Court to have the ultimate decision as if they are the final moral truth of the matter. This is where the major trouble lies, and I will propose a solution for it later in this paper.

To properly assess the balance of power, it is useful to look at the "secret weapon" of sorts that the legislatures have at their disposal in section 33, the Notwithstanding Clause. There is no question that the clause was added to the Charter to appease the provinces. Inherent in its inclusion is the recognition that the Court possesses great power in the review process, so a provision was called for to give the legislatures similar power. It is when we identify that the Notwithstanding Clause was included to even the odds that Supreme Court superiority is more evident. This is because the Notwithstanding Clause has been stigmatized, a political taboo that has barely ever been enacted and thus leaves the legislatures at a distinct disadvantage.

The baggage that comes with the Notwithstanding Clause is no fault of the Supreme Court. The Clause can still be enacted, but seems to be dead in the eyes of most politicians. If we give any weight to the belief that the Court holds power over the legislatures, it seems that an attempt at bringing the Notwithstanding Clause back into the good graces of the public should be strongly considered.

The main question that needs to be answered is why did the Notwithstanding Clause fall into disfavour? We would be best served by looking at the most famous instance of when it was enacted. Since it is enacted so rarely, and has been the centre of major controversy, 
it seems that past experience is a main reason to steer clear of the clause.

In the 1988 case Ford $v$. Quebec, the Quebec government famously enacted the clause to override the provision of freedom of expression and equality rights in the Charter, by restricting the posting of any commercial signs in a language other than French. The Notwithstanding Clause was removed when the law was rewritten after the designated five year period (Ford $\mathrm{v}$. Quebec). It seems that a major consequence of this application is that some may now view section 33 as the way that Quebec managed to deny someone's Charter rights. This was a bad way to illustrate the power that the clause is capable of giving legislatures, and even the Quebec government realized this eventually. Not only does it show people that their Charter rights can be taken away by a government majority, it also shows that governments can be mistaken when enacting it.

Manfredi explains that the stigmatization of the legislative override offered by section 33 may also stem from three misconceptions.

First, people tend to misunderstand that the Supreme Court does not have the exclusive right to constitutional interpretation, and that the legislatures are supposed to be equally involved. Second, there is the general distrust people have in politicians particularly that they will adopt policies which are not in the best interest of their constituents. Third, there is the misunderstanding that appealing to the Supreme Court is the best way to settle fundamental moral questions (Manfredi 2001: 195). Howard Leeson also considers another reason similar to the argument from Morton that legislatures would prefer to play it safe, not "rock the boat" so to speak, and defer potentially divisive issues to the Court. He states that this is unlikely, but it may give us some insight into the growing trend of avoidance in legislatures (Leeson 2000: 18). Both Leeson and Manfredi offer good reasons why the evasion of section 33 has continued. If we take their ideas, and combine them with past experiences, there is plenty of 
motivation behind rejecting the Notwithstanding Clause as a viable political option.

With the Notwithstanding Clause seemingly damaged beyond repair, legislatures are at a distinct disadvantage when it comes to rights disputes. Leeson suggests that the Notwithstanding Clause needs to be evoked more often (Leeson 2000: 2). This seems like the best way to get the Clause back into the good graces of the public. The more it is avoided the more it becomes stigmatized and deteriorates as a practical solution to rights disputes. Furthermore, the longer it is dormant the longer legislatures put themselves at the mercy of the decisions of the judiciary. Legislatures get caught up in a vicious cycle of feeding the conception of something which continues to hold them down the chain of command. Bringing the Clause into a positive light will be extremely challenging particularly because it hinges on the trust of the general public in their governments to make good decisions. This means that a key component of legislatures regaining their power may lie in regaining the confidence of voters, which does not seem to be happening currently.

The difficult task of rebuilding the Notwithstanding Clause is just a part of the complications that need to be sorted out to regain the balance of power. There also needs to be some reforms on the side of the judiciary. There has to be something to add legitimacy to the selection of Supreme Court justices. People are going to balk at the idea of appointed officials no matter what position they hold. There will always be the question of the certain "connections" they possess to get where they are. Perhaps a vote is in order, either by the legislatures or by the constituents themselves, which could entail a restructuring of the amount and traits of the justices who are selected. It is tricky to point at one way to work on this downfall, and admittedly these are only broad ideas. The point is that the legitimacy of the Supreme Court needs to be seriously examined, or else questions will continue to linger.

Another thing that needs to be addressed is the finality that Supreme 
Court decisions entail. This is

troubling because it assumes that the

Supreme Court is the final word on

Charter interpretation, and that they

cannot be swayed by certain biases or

partiality. This finality can be hard to swallow given that the judges are appointed rather than elected by those whom they are ruling over.

Furthermore, as Leeson states, since

judges are going to be of a certain type

- well-educated, elite in some sense (at least academically), it may be argued that they do not properly represent the general population (Leeson 2000: 3). These troubles Leeson mentions seem a little farfetched but still important. There is certainly a disconnect that is apparent when perceived elites are ruling over everyday citizens. It is not clear, however, what can be done about such a disconnect. To be a Supreme Court justice automatically puts one into a rather elite class, no matter their background. This account also does not leave us with much of an alternative. Would we rather that our judges are only moderately educated? This answer is obvious. We want intelligent people dealing with such serious matters.

Leeson's concerns of elitism and the perceived lack of representation are important issues to consider nonetheless when discussing the finality of Supreme Court decisions. We need to find a way to apply an effective check and balance to the Court. Some may argue that this would be inefficient, that there must be a certain point where some entity makes the final judgment. Indeed a final decision-maker would be the best choice if it was always in our best interest, but we know that judges can make mistakes just like anyone else. These mistakes can undoubtedly cause an uproar which can then impact the legislatures, cutting into their efficiency. On top of the public outcry, there is also the lack of efficiency that comes with legislatures re-tooling and altering legislation to the demands of the Court. It would seem at first glance that giving the Court the final word is most efficient, but when taking overall productivity into account it is not entirely clear that this is the case. 
Therefore, it would seem that looking at alternative routes for shifting power could prove to be worthwhile.

There are a few ways that an even playing field between the Supreme Court and the legislatures could be achieved. To begin, as touched on earlier, there needs to be a way of selecting Supreme Court Justices that can be seen as more legitimate and fair than the current practice of appointment. Perhaps a Canada-wide vote is too much to ask for, but maybe co-operation between federal and provincial legislatures in the appointment would be seen as a practical solution.

There also needs to be a way for Supreme Court decisions to be disputed by legislatures. This may be through the Notwithstanding Clause becoming a respectable option, by developing more of a dialogue between the two parties, or something else. Neither the legislatures nor the Supreme Court are going to get things right every time. The difference is that when the legislatures go wrong they are corrected by the Court but when the Court goes wrong, either one's position needs to be changed or a repeal needs to be made to the same Supreme Court with a hope of changing their minds. The key is getting away from creating the false impression that one group of people always has the best answer.

The most important thing that is needed is willing co-operation. The Supreme Court needs to recognize that the balance of power needs to be altered, and be open to making such a change. This may be extremely hard to achieve because a kind of inertia is to be expected with power structures. Those who are perceived to have an unfair advantage often refuse to recognize the discrepancy, are ignorant of it, or have no incentive to change it. To get the Supreme Court to acknowledge that the power structure is unbalanced would be hard enough; to get the Court on board with fixing the situation seems even harder. There somehow needs to be the recognition that this would be what is best for Canada as a federation.

It is important for any federation to be based on ensuring 
that responsibilities are shared fairly. For one party to hold considerable power over another is to violate the idea of federalism. No longer is there collaboration toward a greater good, instead there are commands handed down considered most important by the most powerful. The structure of power in Canada when it comes to disputes looks very much like this, and therefore puts the very tenets of federalism at risk. If we are committed to maintaining a strong federalism, we need to ensure that the shared responsibilities are in fact shared. Whether this is done through a change in the Supreme Court selection process, a strengthening of the Notwithstanding Clause, or building a dialogue between the Court and the legislatures, we need to decide if we really want federalism or if we prefer to delude ourselves into thinking we do but only when convenient.

\section{Works Cited}

Ford v. Quebec. 1988. 22 Nov. 2008 <http://csc.lexum.umontreal.ca/en/1988/1988rcs2-712/1988rcs2-712.html>.

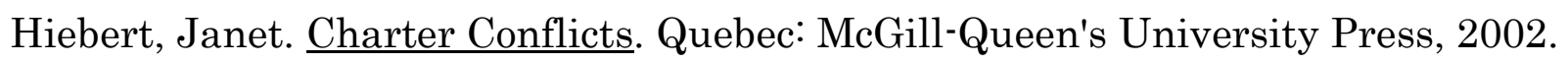

Kelly, James B. "The Supreme Court of Canada and the Complexity of Judicial Activism." The Myth of the Sacred. Quebec: McGill-Queen's University Press, 2002. 97-122.

Leeson, Howard. " Section 33, The Notwithstanding Clause: A Paper Tiger?" IRPP Vol. 6: 4 (June 2000): 1-24.

Manfredi, Christopher P. Judicial Power and the Charter. Don Mills: Oxford University Press, 2001

Morton, F.L. "Dialogue or Monlogue?" Policy Options (Apr. 1999): 23-26.

Smith, Jennifer. Federalism. Vancouver: UBC Press, 2004. 